\title{
Javier Álvarez-Mon, "Aesthetics of the Natural Environment in the Arts of the Ancient Near East: The Elamite Rock-Cut Sanctuary of Kurangun"
}

\section{Yasmina Wicks}

\section{(2) OpenEdition Journals}

Electronic version

URL: http://journals.openedition.org/abstractairanica/44817

DOI: $10.4000 /$ abstractairanica. 44817

ISBN: 1961-960X

ISSN: 1961-960X

Publisher:

CNRS (UMR 7528 Mondes iraniens et indiens), Éditions de l'IFRI

Electronic reference

Yasmina Wicks, « Javier Álvarez-Mon, "Aesthetics of the Natural Environment in the Arts of the Ancient Near East: The Elamite Rock-Cut Sanctuary of Kurangun" ", Abstracta Iranica [Online], Volume 37-38-39 | 2018, document 3, Online since 30 December 2018, connection on 28 September 2020. URL : http://journals.openedition.org/abstractairanica/44817; DOI : https://doi.org/10.4000/ abstractairanica. 44817

This text was automatically generated on 28 September 2020 .

Tous droits réservés 


\title{
Javier Álvarez-Mon, “Aesthetics of the Natural Environment in the Arts of the Ancient Near East: The Elamite Rock-Cut Sanctuary of Kurangun"
}

\author{
Yasmina Wicks
}

\section{REFERENCES}

Javier Álvarez-Mon. "Aesthetics of the Natural Environment in the Arts of the Ancient Near East: The Elamite Rock-Cut Sanctuary of Kurangun" in Brian A. Brown and Marian H. Feldman (eds.). Critical Approaches to Ancient Near Eastern Art. Boston-Berlin: De Gruyter, 2014, p. 741-772.

In part VI of this edited volume, entitled "Making and Defining Space", the Elamite highland tradition of rock relief carving in open-air sanctuaries takes its rightful place amongst the artistic production of the ancient Near East alongside treatments of art from Ebla, Assyria and Achaemenid Iran. Taking the specific example of the rock-cut sanctuary of Kurangun perched high on an outcrop overlooking the Fahliyan river, the author explores human aesthetic experiences of the natural environment in the past, and how these experiences were interwoven into religious belief and practice, and the production and use of art. Harnessing the awe-inspiring agency of their natural setting, which includes a substantial body of water, the Kurangun reliefs could be seen to formalise religious experience and human-divine relations in the open air (versus in a temple) by literally setting in stone the interaction between a divine couple dispensing water, the natural environment (water and fish), and a group of human worshippers. Long after its original carving in the 17 th/16th century $\mathrm{BC}$, the relief was expanded sometime around the 9 th/8th century $\mathrm{BC}$ with the addition of more worshippers, and 
their number was augmented again in the 7th/6th century BC. The analytical framework for the examination of the relief draws on the author's personal experience of this magnificent site in combination with concepts of nature and aesthetics put forward by heavy-weight philosophers such as St. Thomas Aquinas and Immanuel Kant. As well as offering an important discussion of a site whose social, political and ritual significance extended across more than a thousand years, the author challenges us to move beyond our modern tendency to view the natural world in dislocation from the human one, in order that we might better understand the impulses driving the selection of sites in the natural environment as locations for engendering religious experience.

\section{AUTHORS}

\section{YASMINA WICKS}

Department of Archaeology, The University of Sydney 